\title{
Dispelling the Myth of How to Develop Enterprise/Entrepreneurship Skills in University Students: A Staff Perception Study
}

\author{
Track Dinning \\ Faculty of Education, Health and Community, Liverpool John Moores University, Liverpool, UK \\ Email: T.M.Dinning@ljmu.ac.uk
}

Received 16 July 2015; accepted 15 August 2015; published 18 August 2015

Copyright (C) 2015 by author and Scientific Research Publishing Inc.

This work is licensed under the Creative Commons Attribution International License (CC BY). http://creativecommons.org/licenses/by/4.0/

\section{(c) (i) Open Access}

\section{Abstract}

The teaching of enterprise/entrepreneurship skills in higher education institutions is fast becoming a growing field of interest (Rae, 2007) with a heightened curiosity into the mechanism of how this can be facilitated in non-business subjects, as it embellishes both employability and self-employability skills within graduates (Akpan \& Etor, 2103). Accordingly this study sets out to investigate staff perceptions of teaching such skills and establishes some of the barriers faced when asked to embed enterprise/entrepreneurship skills. Through the use of cluster sampling and a single online survey both qualitative and quantitative data was collected and subsequently analysis was conducted using thematic mind maps and percentages. The findings indicated that staff are generally aware what teaching methods can be utilised to develop enterprise/entrepreneurship skills, with at least $\mathbf{7 0 \%}$ of respondents finding methods such as role play, brainstorming, problem based learning, networking, use of pitches, use of case studies appropriate. Curiously out of $77.5 \%$ of staff who stated that enterprise/entrepreneurship was relevant in their subject only $52 \%$ said that they did in fact embed the skills in their curriculum, suggesting a lack in the clarity of meaning and expectation from their university. The implications of this research are discussed in relation to the need for clear guidance on terminology from any university setting about to embed enterprise/entrepreneurship within their programmes.

\section{Keywords}

Higher Education Enterprise, Entrepreneurship, Pedagogies 


\section{Introduction}

As the UK witnesses a shift in the economic climate leading to fewer employment opportunities for graduates (Rampell, 2011), the development of entrepreneurial skills is seen as a way to drive economic growth and job creation (Matlay, 2006). Research into how enterprise/entrepreneurship (hereonin referred to as EE) is being taught in universities is becoming more widely published (Gibb, 2002; Dollinger, 2003; Matlay, 2012) from traditional models of business school programmes through to disciplines that encourage skills and opportunities for their students in a more stealth-like manner. It is not the intention of this study to explore these models but to look more specifically at the type of teaching methods being used and their appropriateness to the development of student EE skills. Working for a university whose strategy includes'entrepreneurship at the heart of the student experience', does beg the question of meaning as, without context, staff are left in the dark over the institution's understanding of such a statement. Lack of context, together with a lack of definition, makes it extremely difficult for programme teams to know how to respond to such a strategic aim.

It has been recognised that entrepreneurship programmes are not always the best solutions to providing students with entrepreneurial experience. For example, Hytti and Gorman (2004) considered 50 enterprise education programmes from a range of countries to find over $60 \%$ of the courses used traditional teaching methods such as lecturing, whilst just 34\% of courses actually allowed their students to set up and run a business, reducing to just $16 \%$ using games and competitions. Similarly, Mwasalwiba (2010) noted the most common subjects taught in entrepreneurship programmes were theoretically based. Therefore, if universities are to give students entrepreneurial experience, they need to go beyond theoretical lectures and bring in real world experience. (National Council for Graduate Entrepreneurship, 2008). For non-business programmes, the entrepreneurial experience needs to be understood in the context of the subject using a range of modern pedagogical approaches.

It is the intention of this paper to develop knowledge of staff perceptions on different teaching pedagogies as they relate to developing EE skills in students from non-business degrees. In addition the paper will discuss some of the barriers to embedding EE skills within a non-business context.

\subsection{Meaning and Understanding}

In order to research a field of study it is good practice to ensure that any terminology is clearly defined from the outset (Hytti \& Gorman, 2004). In the area of entrepreneurship there has been much debate over terminology and definitions (Ahmad, 2008) which make it difficult to define specifically the subject area of this research. Terms such as enterprise, entrepreneurship and entrepreneurial education are all used interchangeably, as concluded by Mwasalwiba (2010) in a study that reviewed 108 articles on entrepreneurship for its objectives, teaching methods and impact factors. Gibb (1993) initially suggested that, in fact, entrepreneurship and enterprise education are conceptually the same but contextually different. His work offers that the context focus depends on the country where the subject is being taught. For the UK, Gibb underlines that enterprise education is the more common term used, yet in more recent literature the use of entrepreneurship is becoming frequently employed (Bennett, 2010: Rae, 2010). The European Commission (2008), for example, suggests that entrepreneurship education can support people in everyday life and should not be confused with business and economic studies (Gibb, 2002). This supports earlier research by Jones and English (2004) in which entrepreneurship education can be considered a process of providing students with self-esteem, knowledge and the confidence to act on opportunities; and needs to be defined in a much broader context (Brown, 2000). It is now recognised that such activity would benefit both anew business start-up and/oremployer (Rae, 2007). A further interesting difference is the NCGE (2008) who suggests that enterprise is a notion that develops the enterprising person and entrepreneurial mind-set, whilst clearly in literature by Ohia (2009 cited in Akpan and Etor, 2013) developing entrepreneurial mind-sets and capabilities is the primary goal of entrepreneurial education. Foyolle (2009, cited in Aristo 2012) further adds to this definition with the notion that entrepreneurial education also includes idea generation and innovation. Such mixed use of terminology does cause confusion for academic staff when starting to establish a knowledge in the subject and embedding this knowledge into their curriculum.

In a published framework for enterprise and entrepreneurship education, the QAA (2012) presents some standardisation to the terminology in this subject area. The framework clearly states that enterprise education is about a process of equipping students with the ability to generate ideas and develop a skill set to make things happen, thus developing an entrepreneurial mind-set. The undertaking of these skills in the context of a subject 
discipline has in the past been described as enterprise, an all-inclusive concept (Price 2004), whilst entrepreneurship education has been more focused in equipping students with skills, knowledge and attributes to enable them to apply the skills in the context of a new venture or business (QAA, 2012) and thereby turn ideas into actions of value (European Commission, 2008).

This clarity of definition will form part of the discussion of this paper, however, for the purposes of the data collection, the terms enterprise/entrepreneurship education will be used as one term so staff can answer from their perspectives without imposing new definitions prior to collection of data.

\subsection{Approaches to Teaching}

With a disparity in definition (Mwasalwiba, 2010) comes confusion with how EE can be taught. Gibb (2002) argued in the early research of this field that if universities are to teach entrepreneurship then more action orientated teaching styles need to be adopted to promote creativity and problem solving by students. Some ten years on, (QAA, 2012) suggested pedagogical approaches for enterprise need to focus on experiential learning and adopt a more activity learning approach. Whilst courses that teach about entrepreneurship tend to use more traditional pedagogies such as lectures, set texts and exploring theories around business start-up, entrepreneurship education is taught through practical business skills, projects, case studies, formal lectures and business simulations which are more passive in nature and less effective in influencing a student's entrepreneurial attributes (Honig, 2004: Bennett, 2006). Arasti, Falavarjani and Imanipour (2010) found that the three most used methods are lecturers, case studies and group discussions. In the context of producing a business plan, the business plan itself is used as a method of assessment (Jones \& Penaluna, 2013) not the method of teaching. However, allowing students to run their venture through a group project was noted to be a critical success factor at the end of the programme (Arasti, Falavarjani, \& Imanipour, 2010), rather than producing a business plan which bears little resemblance to the actual path that students would take if setting up a business (Mullins \& Komisar, 2009).

What is interesting is that Matlay (2006) points out that the growing body of knowledge tends to be driven by the business school within the university and lack reference to a range of conceptual and contextual areas. More recently Pittaway \& Edwards (2012) has started to this gap address by using a population of academics from non-business courses.

Rae (2010) brings to this subject arena the concept of learning about, rather than learning for, in which learning about entrepreneurship is recognised to take place beyond the classroom through experiential pedagogies and discover type activities (Rae 2010), acquiring skills and capabilities such as those described by Price (2005) and applying them to real world problems and opportunities (Penaluna \& Penaluna, 2008). Jones, Matley and Martiz (2012) would offer that these entrepreneurial skills are infact life competencies used across life and most certainly should not be associated with business start-up. Instead they suggest the use of scenarios to develop the entrepreneurial mind-set and its value towards employability and social enterprises. Such education should be learner centred through experiential and discovery type pedagogies (Pittaway \& Cope, 2007: Rae, 2010) and should embrace new technologies (McKeown et al, 2006). Smith (2006) in her research has suggested that as there has been an increase in the use of virtual learning environments in the private sector, perhaps programmes should be emulating this change and using similar technologies.

It is about creating a learning environment where students are recognising and acting upon opportunities (Rae, 2010), where students wanting to learn is at the heart of the experience (Race, 2006) and from that comes learning through a ripple type effect, from the students wanting to learn, through to students' reflection and assessing learning (Race, 2007). Through reflection the student becomes the creator of his own knowledge and experiences (Higgins, Smith, \& Mohammed, 2013). Rae and Cranwell (2000) offer that project based activity where the experience is hands-on, required proactive behaviour is essential. There seems here to be some comparable literature in this area with the QAA (2012) pedagogical approaches for enterprise. Bennett (2006: p. 70) described "the attribute development approach" where students are active in the learning environment, lecturers facilitate, not control, through role play, simulations, team projects and brainstorm; they are not listening and taking notes (Rae, 2000). Whilst it now appears to be recognised that authentic experiential experiences are vital, they are still lacking in programmes (Jones, Matley, \& Martiz 2012). Teaching of entrepreneurship needs to be in the context of the subject, so an understanding of the subject and audience is essential (Jones 2011 in order that programme learning outcomes can be framed to suit the students and subject (Fayolle and Gailly, 2008) and can be clearly stated at the start of the curriculum. Developing an enterprising/entrepreneurial mind-set, behav- 
iours and attitudes are crucial starting points for a student as the foundation upon which to build the more focussed business skills (Hannon et al, 2006). Mwasalwiba (2010) neatly categorizes the teaching pedagogies into two; traditional "passive" and innovative "active" which provides a distinction between methods associated with the traditional teaching in a business school and the theory of entrepreneurship and the more recent view of enterprise/entrepreneurship skills being taught in an "active” environment as life skills for everyone (Matley, 2006).

\subsection{Barriers to Teaching}

Jones and Irdale (2010) suggest that a major challenge to the teaching of enterprise education lies in the lecturer's ability to be flexible and adaptive to new teaching methods to stimulate enterprise skills in their students. Using an innovative active Mwasalwiba (2010) pedagogical approach to enterprise/entrepreneurship education, lecturers need to develop a teaching style that allows students to learn while doing, make mistakes, develop creativity, problem solve and move away from the traditional didactic learning. Challenges can exist in the leadership of a university to allow for this shift towards a more entrepreneurial approach (Hornqvisrt \& Leffler, 2014) for example, if class size and teaching spaces do not allow for such activity (Alkpan and Elor, 2013). Other constraints by Alkpan and Elor (ibid) include funding and poor mind-sets of students towards the subject, whilst Hegarty (2006) suggests it is the academics' attitude and understanding of the subject that can lead to staff not feeling confident enough to embrace the concept in their teaching. Specifically, from a non-business aspect, Henry (2013) offers that it is the lack of legitimacy that creates barriers as the non-business subjects have less institutional resources.

\section{Methodology}

Research was carried out within one faculty of a UK university, using a single online questionnaire that was designed to capture both qualitative and quantitative data through the collection of both structured and free text. Through a process of cluster sampling, participants were volunteers from a population of university academic staff teaching on non-business undergraduate programmes. All contact details could be accessed through the university email system. The survey was initially sent to 120 staff, from which 40 responses were collected.

\subsection{Questionnaire}

To gather the data, a single online survey, which can be found in Appendix 1 was used. This comprised a mix of both open and closed questions. In addition, participants were presented with a series of statements and, using a Likert scale, asked to note their levels of agreement to each statement. Furthermore, participants were presented with a list of 20 pedagogical approaches to teaching, taken from work by Gibb, Hannon, Price and Robertson (2010). Participants were asked to consider if they perceived the different pedagogies as a way of developing EE skills. The Bristol Online Survey Tool was used to both create and administer the questionnaire which allowed for data to be easily compiled from each participant to allow for analysis.

\subsection{Procedure}

Following ethical approval from the university, there were 4 simple stages to the methods section. The designing of the questionnaire was via a review of 6 internal critical friends and pilot testing with 6 external colleagues. Bristol online was used as the institutions' preferred platform. Feedback was taken on board and the final questionnaire was devised. The link to the survey, which remained live for 4 weeks, was sent out via email to 120 potential participants to elicit responses, during which time one reminder email was sent out two weeks into the data collection period. All responses were automatically saved within the Bristol online system.

\subsection{Data Analysis}

Finally the data was analysed through the use of themed mind mapping for the free text and simple percentages for the quantitative responses. In questions where a Likert scale was used the means were calculated to establish if there was a tendency in the answer towards either agree or disagree. After an initial look at the data, cross tabulation was done for a selected number of questions based on author perception of possible interesting data. 


\section{Results}

\subsection{Meaning and Understanding}

When asked what EE means to them, a greater number of respondents agreed/strongly agreed to the statements that "it is about teaching students business skills" see Table 1, rather than setting up a business, to become employed or writing a business plan. Only $12.5 \%$ agreeing/strongly agreeing that it was about "getting students to write business plans".

\subsubsection{What Does Enterprise/Entrepreneurship Mean to You?}

There are five main emerging themes from the answers to the question, see Figure 1.

- Students' development and acquisition of real world skills/entrepreneurial skills.

- Provide an alternative learning environment.

- Expand students’ poetic career avenue.

Table 1. What is enterprise/entrepreneurship?

\begin{tabular}{lcccccc}
\hline & Totally agree (1) & Agree (2) & Neither disagree/agree (3) & Disagree (4) & Strongly disagree (5) & Mean \\
\hline $\begin{array}{l}\text { Encouraging students to } \\
\text { start a business }\end{array}$ & $7.5 \%$ & $17.5 \%$ & $35 \%$ & $27.5 \%$ & $12.5 \%$ & 3.2 \\
$\begin{array}{l}\text { Getting students becoming } \\
\text { self employed }\end{array}$ & $7.5 \%$ & $22.5 \%$ & $35 \%$ & $27.5 \%$ & $7.5 \%$ & 3.02 \\
$\begin{array}{l}\text { Teaching students business skills } \\
\begin{array}{l}\text { Getting students to write a } \\
\text { business plan }\end{array}\end{array}$ & $17.5 \%$ & $40 \%$ & $20 \%$ & $15 \%$ & $7.5 \%$ & 2.2 \\
\hline
\end{tabular}

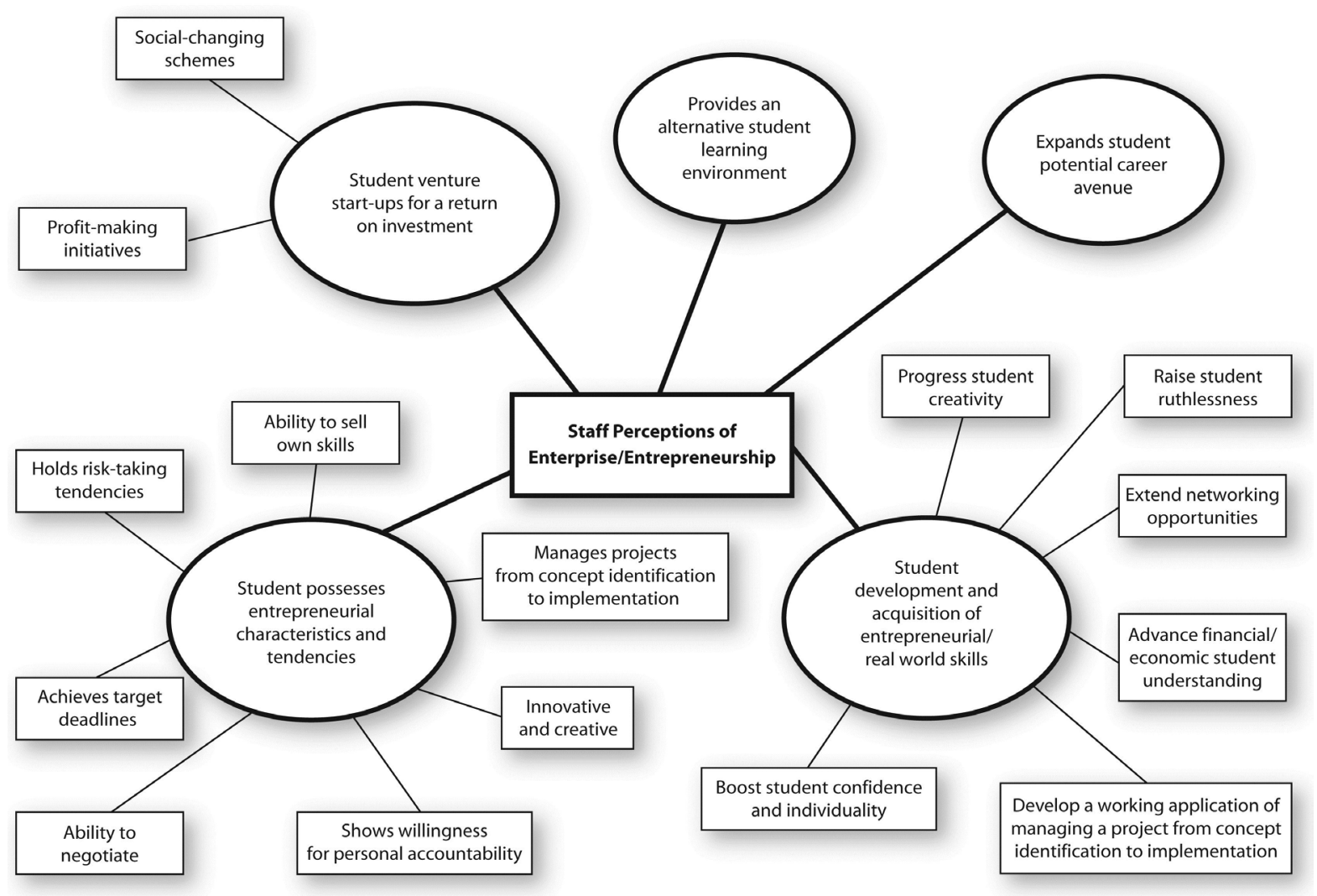

Figure 1. Themed mindmap to illustrate the responses to the questions "what does enterprise/entrepreneurship mean to you?”. 
- Student venture start-ups for a return on investment.

- Students possess entrepreneurial characteristics and tendencies.

\subsubsection{What Does Enterprise/Entrepreneurship Mean in the University?}

There are four main emerging themes from this question, see Figure 2.

- Future student's employment preparation.

- Embedding entrepreneurship into the programme through teaching and learning methods.

- Criticism of the institutional plan.

- Staff-students support in development of entrepreneurial competencies.

\subsection{Approaches to Teaching}

Staff perception of teaching approaches are shown in Table 2 with over $70 \%$ agreeing/strongly agreeing to the teaching of EE through pedagogies such as role play, brainstorming, problem based learning, networking, use of pitches, use of case studies, debates. Methods that had fewer respondents agreeing were those of business planning, stand-up lectures, drawing, setting up a business and simulations, quizzes.

Table 3 highlights that $77.5 \%$ of the survey respondents agreed/strongly agreed that EE is highly relevant to their subjects, $17.5 \%$ are unsure and just $5 \%$ reporting it is not relevant. With only $45 \%$ of respondents stated that they do embed EE into their teaching, this suggests that $32.5 \%$ of staff who agreed it is relevant do not embed it. This finding gave rise to the cross tabulation of these two questions that of relevance to subject and whether staff did embed EE in their teaching, see Table 2. These results showed that of the 77.5\% of respondents that do believe EE is relevant in their subject area, 52\% do embed EE in their teaching (40\% of the sample).

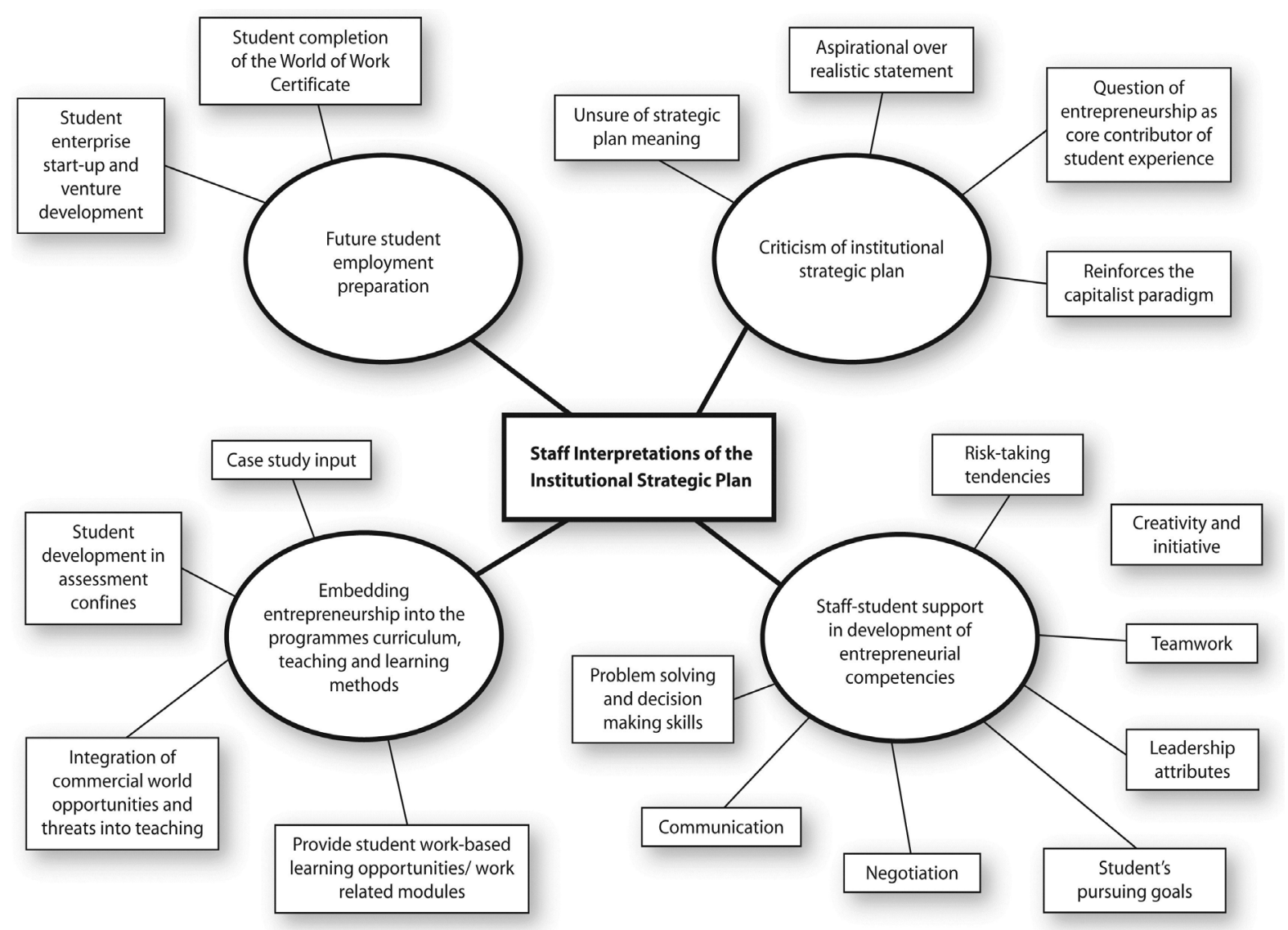

Figure 2. Themed mind map to illustrate the responses to the questions "what does enterprise/entrepreneurship mean in your university’s strategic plan?”. 
Table 2. Results showing respondents' perceptions to the extent they agree with the approaches as ways for teaching enterprise/entrepreneurship.

\begin{tabular}{cccc}
\hline \multicolumn{2}{c}{ To what extent do you agree with the following approaches as ways for teaching enterprise/entrepreneurship } \\
\hline & Totally agree/agree & Neither disagree or agree & Disagree/strongly disagree \\
\hline Stand up lectures & $27.5 \%$ & $37.5 \%$ & $35 \%$ \\
Seminars & $70 \%$ & $22.5 \%$ & $7.5 \%$ \\
Business planning & $52.5 \%$ & $35 \%$ & $12.5 \%$ \\
Drama & $40 \%$ & $42.5 \%$ & $15.5 \%$ \\
Drawing & 42.5 & $32.5 \%$ & $25 \%$ \\
Role play & $70 \%$ & $15 \%$ & $15 \%$ \\
Brainstorming & $72.5 \%$ & $20 \%$ & $7.5 \%$ \\
Problem based learning & $85 \%$ & $5 \%$ & $10 \%$ \\
Business simulations and panels & $62.5 \%$ & $30 \%$ & $7.5 \%$ \\
Set up a real business & $52.5 \%$ & $30 \%$ & $17.5 \%$ \\
Case studies \& networking & $80 \%$ & $10 \%$ & $10 \%$ \\
Pitches & $70 \%$ & $20 \%$ & $10 \%$ \\
Quizzes & $40 \%$ & $50 \%$ & $10 \%$ \\
Debates & $67.5 \% \%$ & $25 \%$ & $15 \%$ \\
Work shadow & $75 \%$ & $22.5 \%$ & $1.5 \%$ \\
\hline Finding ideas for business & $65 \%$ & $27.5 \% \%$ & $10 \%$ \\
\hline
\end{tabular}

Table 3. Results showing cross tabulation of relevance of EE to my subject and embedding EE in a subject.

\begin{tabular}{cccc}
\hline $\begin{array}{c}\text { Do you believe that enterprise education/entrepreneurship } \\
\text { education is highly relevant to your subject area }\end{array}$ & \multicolumn{2}{c}{$\begin{array}{c}\text { Do you embed enterprise/entrepreneurship skills } \\
\text { into your teaching? }\end{array}$} \\
\hline Totally agree/agree & Yes & No & Don't know \\
Neither disagree or agree & $40 \%$ & $17.5 \%$ & $20 \%$ \\
Totally disagree/disagree & $5 \%$ & $5 \%$ & $2.5 \%$ \\
\hline
\end{tabular}

\subsection{Barriers}

When asked the question "Have you ever experienced any barriers to embed enterprise/entrepreneurship skills into your teaching?” 27.5\% said “yes”, 42.5\% said "no” with 30\% responding "don’t know”.

Figure 3 highlights the qualitative comments, that evidence four keys themes:

- Absence of university strategic management and direction.

- Staff knowledge deficiency in the area.

- Time restrictions.

- Staff discord as to the role and value of entrepreneurship education.

\section{Discussion}

\subsection{Understanding What Is Expected}

Ambiguity around the definition has existed for many years. Sewell and Pool (2010) offered that this has in the past given HEI's a free hand to embed the enterprise policy as they saw fit. However, for staff to work efficiently 


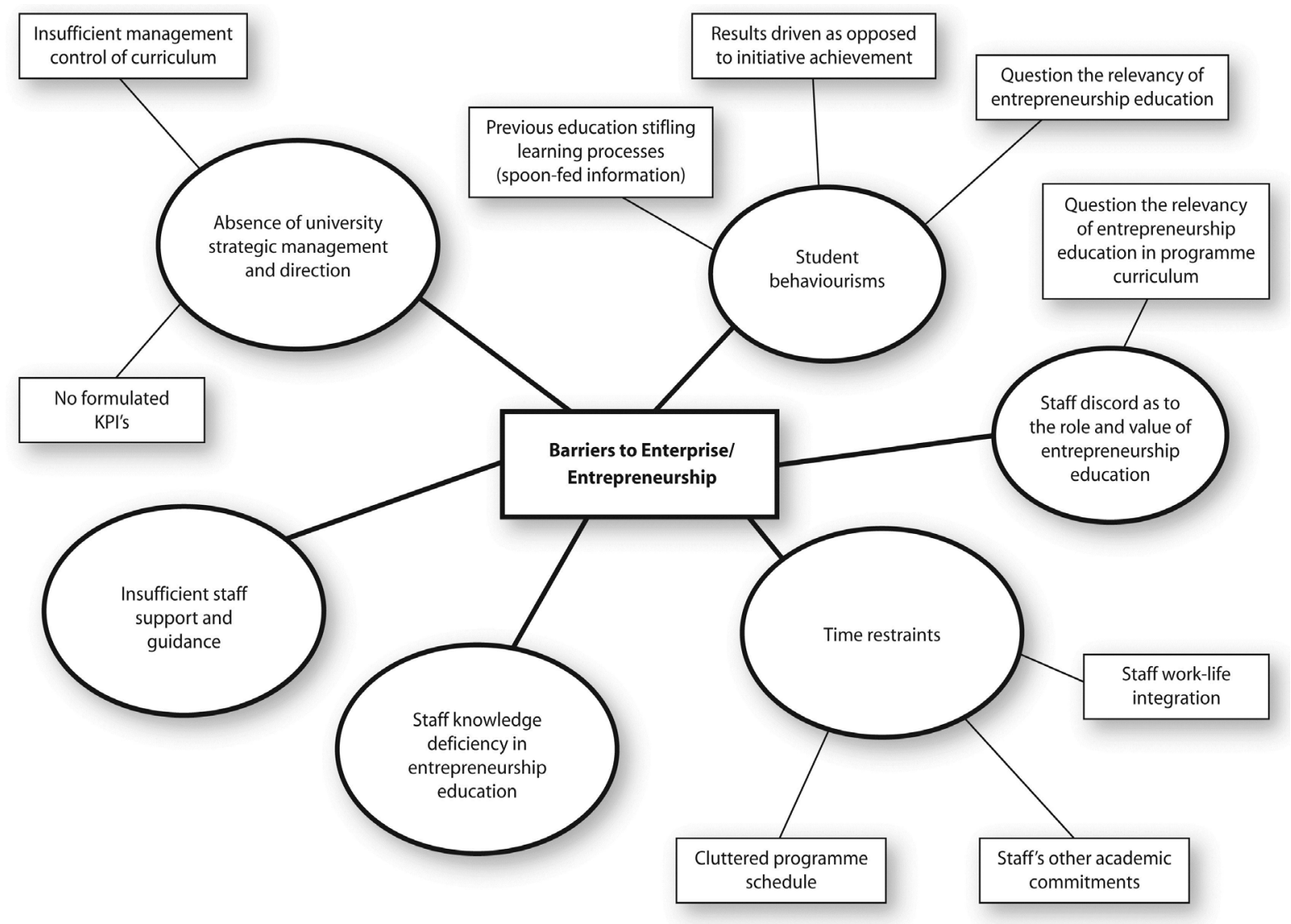

Figure 3. Themed mind map to illustrate the responses to the question "what are the barriers to enterprise/entrepreneur ship?”.

in their roles, this ambiguity needs to be removed. When asked what EE means one respondent commented' this remains a term with no meaning to me and put me off', supportive of earlier findings by Bridge, Hegarty and Porter (2010) where they also considered staff perceptions to entrepreneurship terminology. Moreover their findings also reported comments such as "we are from the ARTs, therefore the terminology is an issue”. Other comments showed a mix in responses from profit making initiatives, innovation and creativity and networking (Bennett 2006), see Table 1. With such a diverse understanding amongst the respondents the author offers that this could be due to the lack of clarity by some from an institutional view point. The results in Figure 2 also demonstrate that staff's perception of what their university expected them to include in their curriculum varied from:

"Students been involved in start-ups".

"I think enterprise skills is about being creative, problem solving towards their studies, future career and life plans”.

"That the curriculum we deliver must embed these skills and opportunities to allow students to demonstrate and develop their entrepreneurship skills and abilities. This should not be confined to typical "business" models, but across every module."

This reported lack of clarity and understanding is again evident from the perceived barriers to the teaching of EE, Figure 3. These show clearly the four core themes in relation to barriers including lack of understanding of how to teach, of expectation from the university, why do it?

Although literature has come a long way in clarifying the terminology, these results would suggest that work still remains to be undertaken to provide clarity of meaning for staff and the context in which they teach the subject. The author would offer that where an institution uses such terminology, some form of guidance is required to support staff on delivering an associated objective/KPI. There are numerous studies available that offer guidance on meaning in. 


\subsection{Teaching Approaches}

Staff reported EE was more about the teaching of business skills (Gibb, 2002) (57.5\% agreed/strongly agreed) rather than encouraging students to set up a business or become self-employed, where only $25 \%$ agreed/strongly agreed which are very encouraging results see Table 1 . This is supportive of much of the existing literature and more recently in the QAA (2012) guidance for UK HEI educators.

On this premise the results related to the respondents' perception on what extent a teaching method allowed for the teaching of EE, (see Table 2) indicated a positive perception of respondents' connecting the approaches to teaching EE. Over 70\% agreeing/strongly agreeing to the teaching of EE through pedagogies such as role play, brainstorming, problem based learning, networking, use of pitches, use of case studies, debates which support existing literature in particular, Mwasalwiba (2010) innovative "active” methods. Whilst not as strong, 52.5\% of respondents were in agreement that pedagogies such as business planning, business simulations can be used to develop the skills supporting literature by Bennet (2006). Stimulatingly in an earlier question only $25 \%$ of respondents said it was about getting students to set up a business, whilst $52 \%$ agreed that setting up a real business could develop the skills. The author suggests that this further supports the need of a clear context to be set, as EE education is something that can support everyday life and skills (Gibb, 2002) and should not be confusing teaching about entrepreneurships as more of a process of business start-up (Honig, 2004; Bennett, 2006).

Two approaches that fewer respondents agreed with (40\%) were drawing and drama, despite being one of the 40 EE pedagogies (Gibb, Hannon, Price, \& Robertson, 2010) and whilst there is no detailed explanation, it does perhaps add to the evidence that there is a lack of understanding on how EE can be taught (Mwasalwiba, 2010). Only $27.5 \%$ of staff believed that the use of stand up lectures were very much appropriate in the delivery of teaching EE, considerably less than the report figure of $60 \%$ in a study conducted by Hytti and Gorman (2004), however their study considered the teaching within a business school setting, rather than non-business subjects as this study projects.

In general, the approaches from Gibb, Hannon, Price and Roberston (2010) are perceived as ways of teaching $\mathrm{EE}$ and given this result the author would have expected to find that all staff who see EE relevant in their subject, also embedding EE, due to the varied list of pedagogies that can be used. This however was not the case (see Table 2), $77.5 \%$ of respondents reported that EE was relevant to their subject but only $52 \%$ of these reported they did embed and 22\% of these respondents that said "no" they did not embed within their teaching. Upon consideration of the free text regarding their understanding of EE, see Figure 1, their responses tended to steer towards the themes of "students venture for return on investment". In addition $20 \%$ of respondents who did not know if they embedded even though they thought it relevant to their subject, all but one wrote that EE was within the theme of students possessing entrepreneurial characteristics and tendencies, in particular making reference to innovation and creativity. Of this $37 \%$ of respondents, all but $5 \%$ agreed/strongly agreed that the list of teaching methods were approaches of teaching EE. These results support the authors' earlier discussion point that clarity is needed to overcome barriers, see Figure 3, where one respondent said "there is no university steer and lack of support for us as staff'. Depending upon the subject being taught, teachers need to understand what it is they need to embed, as a set of skills to develop a mind-set and enterprising students (Ohia, 2009, cited in Akpan \& Etor, 2013) or the process of setting up a business. However staff interpret the subject, EE will determine how it is taught (Bennett, 2006) and staff need to see the relevance of it as one respondent said "not sure it is relevant in my programme" and teach it within the context of the subject (Jones, 2011).

Other barriers reported in this study include lack of time, knowledge and direction, see Figure 3 which is consistent with previous literature (Hegarty, 2006; Hornqvisrt \& Leffler, 2014). Interestingly there was no mention of barriers such as finance as which in previous literature has been a factor (Akpan \& Etor, 2013).

\section{Conclusion}

The results suggest a contradiction exists in the understanding of what an institution requires and what the staff perceive as the meaning of EE in the non-business subjects. Staff are more aware that methods of teaching used today in the their classroom are able to stimulate EE teaching, however there still seems to be a lack of confidence by staff in connecting existing teaching methods to skills development. It is not anexactscience (Hegarty, 2006) making it needful for each subject to consider both the terminology and activity in context for its discipline. Barriers reported are similar to those existing in previous literature, with the exception of financial barriers. The study can, however, conclude that with guidance from the university on terminology and what is ex- 
pected, it is likely that staff are more likely to embed such activity into their teaching. In addition, as the majority of staff do perceive there is a whole range of teaching methods that can be adopted, then with little effort EE could be embedded into more programmes. Whilst this study adds to the body of knowledge in the area of EE education, the literature for non-business subjects is still limited such that there is scope to develop this much further, particularly in subject specific areas.

\section{References}

Ahmad, N., \& Seymour, R.G. (2008). Defining Entreprnurial Activity. Definitions Supporting Frameworks for Data Collection, OECD. Statistics Working Paper 2008/01.

Akpan, C., \& Etor, C. (2013). University Lecturers Perceptions of Entrepreneurship Education as an Empowerment Strategy for Graduate Self-Employment in South—South Nigeria. International Journal of Asian Social Science, 3, 1180-1195.

Arasti, Z., Falavarjani, M.K., \& Imanipour, N. (2010). A Study of Teaching Methods in Entrepreneurship Education for Graduate Students. Higher Education Studies, 2, 2-8.

Bennett, R. (2006). Business Lecturers' Perceptions of the Nature of Entrepreneurship. International Journal of Entrepreneurial Behaviour and Research, 12, 165-188. http://dx.doi.org/10.1108/13552550610667440

Bridge, S., Hegarty, C., \& Porter, S. (2010). Rediscovering Enterprise: Developing Appropriate University Enterprise Education. Education and Training, 52, 722-734. http://dx.doi.org/10.1108/00400911011089015

Brown, C. (2000). Entrepreneurial Education Teaching Guides00-7. In Jones and English. A Contemporary Approach to Entrepreneurship Education. Education and Training, 46, 416-423. www.celcee.edu/publications/digest/Dig00-7.htmlVol.007-7.

European Commission (2008). Entrepreneurship in Higher Education, Especially Within Non-Business Studies. Luxembourg: Office for Official Publications of the European Communities.

Gibb, A. (2002). In Pursuit of a New Entrepreneurial Paradigm for Learning: Creative Destruction, New Values, New Ways of Doing Things and New Combination of Knowledge. International Journal of Management Reviews, 4, $233-269$. http://dx.doi.org/10.1111/1468-2370.00086

Gibb, A., Hannon. P., Price, A., \& Robertson, I. (2010). A Compendium of Pedagogies for Teaching Entrepreneurship. International Educators Entrepreneurship Programme Un-Published.

Hegarty, C. (2006). Its Not an Exact Science: Teaching Entrepreneurship in Northern Ireland. Education and Training, 48, 322-335. http://dx.doi.org/10.1108/00400910610677036

Henry, C. (2013). Entrepreneurship Education in HE: Are Policy Makers Expecting too Much? Education and Training, 55, 836-848. http://dx.doi.org/10.1108/ET-06-2013-0079

Higgins, D., Smith, K., \& Mirza, M. (2013). Entrepreneurial Education: Reflexive Approaches to Entrepreneurial Learning in Practice. Journal of Entrepreneurship, 22, 135-160. http://dx.doi.org/10.1177/0971355713490619

Honig, B. (2004). Entrepreneurship Education: Towards a Model of Contingency-Based Business Planning. Academy of Management Learning and Education, 3, 258-273. http://dx.doi.org/10.5465/AMLE.2004.14242112

Hornqvisrt, M. L., \& Leffler, E. (2014). Fostering and Entrepreneurial Attitude Challenging in Principal Leadership. Education and Training, 56, 551-561. http://dx.doi.org/10.1108/ET-05-2013-0064

Hytti, U., \& O’Gorman, C. (2004). What Is “Enterprise Educations”? An Analysis of the Objectives and Methods of Enterprise Education Programmes in Four European Countries. Education and Training, 46, 11-23. http://dx.doi.org/10.1108/00400910410518188

Jones, B., \& Iredale, N. (2010). Viewpoint: Enterprise Education as Pedagogy. Education and Training, 52, 7-18. http://dx.doi.org/10.1108/00400911011017654

Jones, C., \& English, J. (2004). A Contemporary Approach to Entrepreneurship Education. Education and Training, 46, 416423. http://dx.doi.org/10.1108/00400910410569533

Jones, C., \& Penaluna, A. (2013). Moving beyond the Business Plan in Enterprise Education. Education and Training, 55, 804-814.

Jones, C., Matley, H., \& Maritz, A. (2012). Enterprise Education: For All or Just Some? Education and Training, 54, 813824. http://dx.doi.org/10.1108/00400911211274909

Matley, H. (2006). Researching Entrepreneurship and Education. Part 2: What Is Entrepreneurship Education and Does It Matter. Education and Training, 48, 704-718. http://dx.doi.org/10.1108/00400910610710119

Mullins, J., \& Komisar, R. (2009). Getting to the Plan B. Boston, MA: Harvard Business Press.

Mwasalwiba, E. S. (2010). Entrepreneurship Education: A Review of Its Objectives, Teaching Methods and Impact Indictors. 
Education and Training, 52, 20-47. http://dx.doi.org/10.1108/00400911011017663

Penaluna, A., \& Penaluna, K. (2008). Entrepreneurial Capacity? Entrepreneurial Intent? Assessing Creativity: Drawing from the Experience of the UK's Creative Industries. Paper Presented at IntEnt 2008, Oxford, OH: Miami University.

Pittaway, L., \& Cope, J. (2007). Simulation Entrepreneurial Leaning. Management Learning, 38, 211-233. http://dx.doi.org/10.1177/1350507607075776

Pittaway, L., \& Edwards, C. (2012). Assessment: Examining Practice in Entrepreneurship Education. Education and Training, 54, 778-800. http://dx.doi.org/10.1108/00400911211274882

Price, A. (2005). Creating the Integrated Embedded Enterprise Experience. Leeds Met Press Internal.

Race, P. (2006). The Lecturers Toolkit. London: Routledge.

Rae, D. (2000). Understanding Entrepreneurial Learning: A Question of How? International Journal of Entrepreneurial Behaviour and Research, 6, 145-159. http://dx.doi.org/10.1108/13552550010346497

Rae, D. (2007). Connecting Enterprise and Graduate Employability: Challenges to the Higher Education's Culture and Curriculum? Education and Training, 49, 605-619.

Rae, D. (2010). Universities and Enterprise Education: Responding to the Challenge of the New Era. Journal of Small Business and Enterprise Development, 17, 591-606. http://dx.doi.org/10.1108/14626001011088741

Rae, D., \& Cranwell, M. (2000). Using a Life-Story Approach to Researching Entrepreneurial Learning: The Development of a Conceptual Model and Its Implications in the Design of Learning Experiences. Education and Training, 42, $220-227$. http://dx.doi.org/10.1108/00400910010373660

Sewell, P., \& Dacre Pool, L. (2010). Moving from Conceptual Ambiguity to Operational Clarity: Employability, Enterprise and Entrepreneurship in Higher Education. Education and Training, 52, 89-94. http://dx.doi.org/10.1108/00400911011017708

Smith, K. (2006). Supporting Technology Enhance Enterprise Education: The TE3 Project. Working Paper No. 017/2006, National Council for Graduate Entrepreneurship. 


\section{Appendix 1}

$\underline{\text { Staff perceptions to enterprise and entrepreneurship education: Pedagogies, benefits and barriers }}$

1. What is the subject area you teach? If you do not teach a specific subject area please give further details.

2. What degree programme(s) do you teach on at LJMU?

3. To what extent do you agree with the following statements about enterprise/entrepreneurship? Please rate your answer from 1 - 5 where 1 is totally agree and 5 is totally disagree.

\begin{tabular}{llllll}
\hline 3.1) Enterprise/Entrepreneurship is about encouraging students to start a business. & 1 & 2 & 3 & 4 & 5 \\
\hline 3.2) Enterprise/Entrepreneurship is about students becoming self-employed. & 1 & 2 & 3 & 4 & 5 \\
\hline 3.3) Enterprise/Entrepreneurship is about teaching students business skills. & 1 & 2 & 3 & 4 & 5 \\
\hline 3.4) Enterprise/Entrepreneurship is about getting students to write a business plan. & 1 & 2 & 3 & 4 & 5 \\
\hline
\end{tabular}

4. What does enterprise/entrepreneurship mean to you?

5. "A curriculum with entrepreneurship at the heart of the student's experience" (LJMU strategic plan 2012-2017). What does this mean to you?

6. Do you believe that enterprise education/entrepreneurship education is highly relevant to your subject area?
Totally Agree
Agree
Neither Agree or Disagree
Disagree
Totally Disagree

7. To what extent do you agree that the following approaches are a way for teaching enterprise/entrepreneurship skills? Please rate your answer from 1 - 5 where 1 is totally agree and 5 is totally disagree.

\begin{tabular}{llllll}
\hline 7.1) Use of stand-up lectures & 1 & 2 & 3 & 4 & 5 \\
\hline 7.2) Use of seminars & 1 & 2 & 3 & 4 & 5 \\
\hline 7.3) Use of business planning & 1 & 2 & 3 & 4 & 5 \\
\hline 7.4) Use of drama & 1 & 2 & 3 & 4 & 5 \\
\hline 7.5) Use of drawing & 1 & 2 & 3 & 4 & 5 \\
\hline 7.6) Use of role play & 1 & 2 & 3 & 4 & 5 \\
\hline 7.7) Use of brainstorming with post its & 1 & 2 & 3 & 4 & 5 \\
\hline 7.8) Use of problem based learning & 1 & 2 & 3 & 4 & 5 \\
\hline 7.9) Use of business simulations & 1 & 2 & 3 & 4 & 5 \\
\hline
\end{tabular}




\begin{tabular}{llllll}
\hline 7.10) Get students to set up a real business & 1 & 2 & 3 & 4 & 5 \\
\hline 7.11) Use of case studies & 1 & 2 & 3 & 4 & 5 \\
\hline 7.12) Use of networking & 1 & 2 & 3 & 4 & 5 \\
\hline 7.13) Use of pitches & 1 & 2 & 3 & 4 & 5 \\
\hline 7.14) Use of quizzes & 1 & 2 & 3 & 4 & 5 \\
\hline 7.15) Use of debates & 1 & 2 & 3 & 4 & 5 \\
\hline 7.16) Use of panels & 1 & 2 & 3 & 4 & 5 \\
\hline 7.17) Use of work shadowing & 1 & 2 & 3 & 4 & 5 \\
\hline 7.18) Exercises that relate to finding ideas for business & 1 & 2 & 3 & 4 & 5 \\
\hline 7.19) Use of external speakers & 1 & 2 & 3 & 4 \\
\hline 7.20) Use of competitions & 1 & 2 & 3 & 5 \\
\hline
\end{tabular}

8. Do you embed enterprise/entrepreneurship skills into your teaching?

Yes No Don’t Know

9. Please add below any other teaching approaches you consider to be relevant to teaching enterprise/entrepreneurship skills.

10. What do you believe to be the three most important benefits to your students of enterprise/entrepreneurship education within the curriculum?

$$
\begin{aligned}
& 1 . \\
& 2 . \\
& 3 .
\end{aligned}
$$

11. Have you ever experienced barriers in embedding enterprise/entrepreneurship education into your curriculum?

Yes No Don’t Know

12. If you have answered $\boldsymbol{Y E S}$ to the above question, what are the three most significant barriers?

$$
\begin{array}{|l}
\hline 1 . \\
2 . \\
3 .
\end{array}
$$

13. Would you be willing to take part in a face-to-face interview for 20 minutes in order to extend this research project? If so, then please leave your email address, so I can get in touch with you.

Email Address:

Many thanks for your time in completing this questionnaire. 